\title{
Between Myth and Brand. Aspects of Myth in Marketing Communication
}

\author{
Maciej Czeremski iD https://orcid.org/0000-0003-4906-2045 \\ Institue for Religious Studies \\ Jagiellonian University \\ e-mail: maciej.czeremski@uj.edu.pl
}

\begin{abstract}
The article is aimed at presenting that the features of a myth (known from literature in the field of anthropology, semiotics, and cognitive science) are also present in marketing communication related to shaping the image of brands. However, they are used in a scattershot manner, as specific marketing messages usually use only certain selected features of a myth. The article shows techniques of brand mythologization by combining three features of myths (permanent structure of events, bricolage, counter-intuitiveness) with three possible ways of their application for marketing communication (modeling, export, import).
\end{abstract}

Keywords: myth, brand, marketing, storytelling, monomyth, bricolage, counter-intuitiveness Słowa kluczowe: mit, marka, marketing, storytelling, monomit, bricolage, kontrintuicyjność

\section{Introduction}

Brand mythologization is a desired process from a marketing point of view. Thanks to it, a brand can: 1) become an element of an attractive narrative structure; 2) easily evoke associations between products it represents and attractive abstract values; 3) stand out from the standard background, remaining, at the same time, a concept that can easily be recognized and remembered. To generate the above effects, it is necessary to understand the mechanics of mythological thinking and its relationships with the architecture of the human mind, shaped by the process of evolution. In order to apply the mechanics of mythological thinking to marketing, we have to know how the process of mythologization operates. In practice, there are three relatively separate ways in which mythologization can take place: 1) by transferring the very mechanisms of mythological thinking, albeit without referring to any particular 
mythological system; 2) incorporating a brand into an existing mythological system; 3 ) using elements of existing mythological systems in a marketing campaign. These three methods of mythologization and the three mechanisms of thought characteristic of myths combine to give us nine concrete techniques of brand mythologization.

\section{Marketing needs myths}

Until recently, it had been believed that advertising is the art of praising the merits of a particular product. The most important classic models of advertising are based upon such an assumption. Regardless of the differences that separate these models, they all assume that an advertisement should strive to present a persuasive argument, under the influence of which the consumer will arrive at a decision to purchase a given product or service. Of importance, these models grew in a belief that such an argument requires conveying to the receiver a certain amount of knowledge about the advantages of the given product or service. It had been assumed, therefore, that in the end the customer makes a rational decision.

Today, we know that the issue of rationality in the decision-making process of (not only) consumers has been wrongly overestimated. Numerous studies have univocally shown that we are, as a matter of fact, far less rational than we think we are. Frequently, we first make a decision, and only after the decision has been made do we build up hasty justifications around it. This finding has fundamentally changed the concepts of planning advertisement campaigns. ${ }^{1}$ Yet, the minimization of the importance of rational knowledge about a product does not mean that the importance of the need to advertise the product automatically decreases, for the fact that a given product is chosen on the basis of premises other than those based on rational knowledge does not mean that it is chosen in a random manner. The tasks of advertising remain, therefore, unchanged. The only thing that needs to change is the way advertising should implement them.

For this very reason, marketing has become increasingly interested in myths, righteously seeing in them a natural pattern of communication that shapes attitudes and motivations based on premises other than rational knowledge. ${ }^{2}$ Particularly encouraging here is the success of such brands-icons as Coca-Cola, Nike, HarleyDavidson, or Apple. As a matter of fact, these companies do not owe their triumph to particular characteristics of the goods they produce, but rather to the position these goods have achieved in the structure of culture. This position is, in turn, the result of a marketing strategy that is, to a large extent, based on treating products

${ }^{1}$ R. Heath, The Hidden Power of Advertising: How Low Involvement Processing Influences the Way We Choose Brands, Henley-on-Thames 2001.

2 S. Randazzo, Subaru: The Emotional Myths Behind the Brand's Growth, "Journal of Advertising Research" 2006, vol. 46, no. 1, pp. 11-17; idem, Mythmaking on Madison Avenue: How Advertisers Apply the Power of Myth and Symbolism to Create Leadership Brands, Chicago 1993; C.J. Thompson, Marketplace Mythology and Discourses of Power, "Journal of Consumer Research" 2004, vol. 31, no. 1, pp. 62-80; S. Brown, P. McDonagh, C.J. Shultz, Titanic: Consuming the Myths and Meanings of an Ambiguous Brand, "Journal of Consumer Research" 2013, vol. 40, no. 4, pp. 595-614. 
merely as material representations of a certain concept of reality which captured in a narrative form turns out to be a mythic story. ${ }^{3}$ Products become mere mediums for such attractive myths.

At the beginning, the marketing potential of myth was understood in a structural manner. ${ }^{4}$ Looking at myth from the perspective of Jungian archetypes has also been relatively popular. ${ }^{5}$ This issue has also been investigated from the perspective of the taxonomy of mythical modes formulated by Northrop Frye. ${ }^{6}$ Finally, myth in marketing has been frequently equated with unjustified beliefs, stereotypes, and ideological constructs. The marketing understanding of myth is not, as a result, unequivocal, and this is true for other areas of studies on myth as well. ${ }^{7}$ The current article presents a proposition of at least partial ordering methods of bestowing mythical characteristics on a brand. This proposition is based on the description of the main characteristics of myth and discussing ways in which these characteristics can be assigned to a brand.

\section{What makes a brand a myth?}

Marketing usually concentrates on the effects achieved through the use of the mythical form. It overlooks, however, its characteristic traits or it takes them up in a selective manner. Detaching the function of the myth from its formal or substantial traits is, however, a mistake, as the effectiveness of the myth stems from the way the myth is built. If a marketing message is to adopt this effectiveness, it has to imitate the mythical form. In my opinion, there are at least three characteristics of myth that can be transferred to stories that are to mythologize a given brand. These characteristics are:

${ }^{3}$ L. Vincent, Legendary Brands: Unleashing the Power of Storytelling to Create a Winning Marketing Strategy, Chicago 2002; D.B. Holt, How Brands Become Icons: The Principles of Cultural Branding, Boston 2004; idem, What Becomes an Icon Most?, "Harvard Business Review" 2003, vol. 81, no. 3, pp. 43-49; D.B. Holt, D. Cameron, Cultural Strategy: Using Innovative Ideologies to Build Breakthrough Brands, Oxford 2012; R.W. Belk, G. Tumbat, The Cult of Macintosh, "Consumption, Markets and Culture" 2005, vol. 8, no. 3, pp. 205-217.

4 J. Williamson, Decoding Advertisements: Ideology and Meaning in Advertising, London 1978; S.J. Levy, Interpreting Consumer Mythology: A Structural Approach to Consumer Behavior, "Journal of Marketing" 1981, vol. 45, no. 3, pp. 49-61.

${ }^{5}$ M. Mark, C. Pearson, The Hero and the Outlaw: Building Extraordinary Brands Through the Power of Archetypes, New York 2001; U. Kilinc, The Use of Myths as an Advertisement Strategy at the Age of Social Media, [in:] Handbook of Research on Effective Advertising Strategies in the Social Media Age, Ö.T. Nurdan, Y. Recep (eds.), Hershey 2015, pp. 406-415.

${ }^{6}$ B.B. Stern, Consumer Myths: Frye's Taxonomy and the Structural Analysis of Consumption Text, "Journal of Consumer Research" 1995, vol. 22, no. 2, pp. 165-185; G.V. Johar, M.B. Holbrook, B.B. Stern, The Role of Myth in Creative Advertising Design: Theory, Process and Outcome, "Journal of Advertising" 2001, vol. 30, no. 2, pp. 1-25.

${ }^{7}$ L. Honko, The Problem of Defining Myth, [in:] The Myth of the State, H. Biezais (ed.), Stockholm 1972, pp. 7-19; I. Strenski, Four Theories of Myth in Twentieth-Century History: Cassirer, Eliade, Lévi-Strauss and Malinowski, London 1995; W.G. Doty, Mythography: The Study of Myths and Rituals, Tuscaloosa 2000. 
1. Structure of events,

2. Bricolage,

3. Counter-intuitiveness.

By "structure of events" I understand a characteristic of a myth's sequence of actions that develop into a relatively stable course of a heroic story. In turn, the term bricolage, coined by Claude Lévi-Strauss, refers to the manner mythical thinking encodes abstract meanings in the form of concrete objects. ${ }^{8}$ This term can be explained as "tinkering with," and as such it constitutes an opposition to the conscious "engineering" responsible for creating rational discourse. The last of the traits of myth given above, counter-intuitiveness, describes a discrepancy, characteristic of this type of narration, between concepts that create it and intuitive knowledge about reality. This trait has an influence on the appraisal of the appeal and durability of mythical representations.

The above traits of myth are the very characteristics that to a large extent decide about the specificity of a myth. Furthermore, these traits are ways, natural for human beings, of dealing with three fundamental problems that occur in attempts to build a successful marketing campaign. When a marketing message preserves the mythical structure of events, it is treated by the human mind as an interesting story. Bricolage is a successful technique for building unconscious associations between a brand and positively valued abstract categories. Counter-intuitiveness, in turn, enables building a message that is both attractive and easy to remember. A symbolic depiction of brand mythologization understood this way is presented in Figure 1. Below I discuss in a more detailed manner the three characteristics of myth, also pointing out their marketing potential.

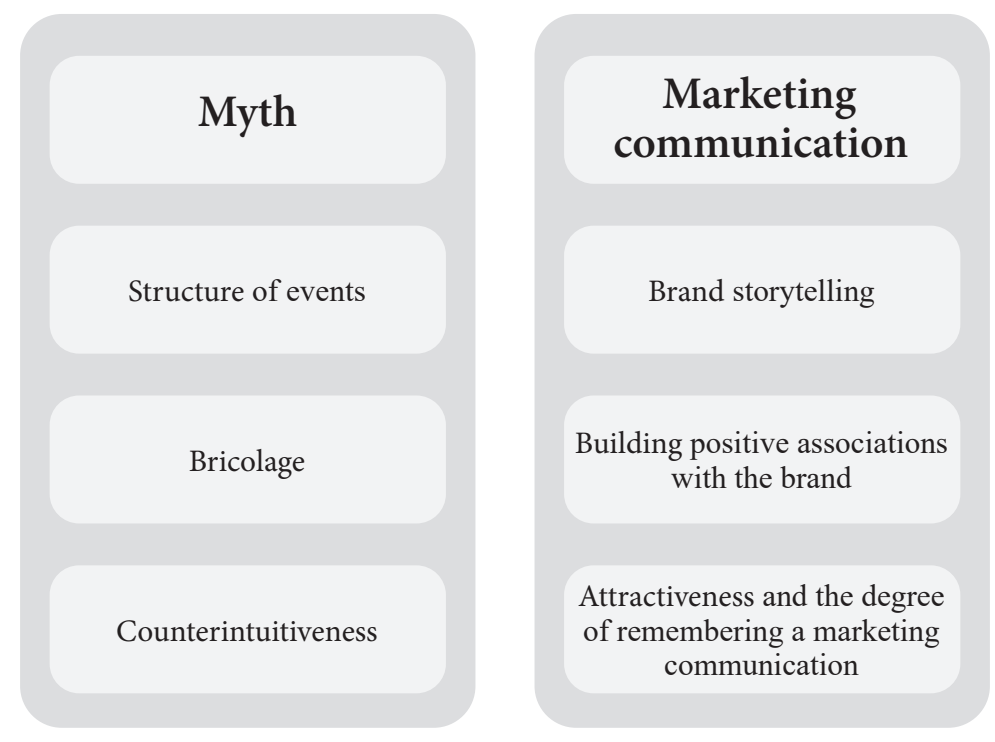

Figure 1. Properties of myth and problems characteristic of marketing communication they solve.

${ }^{8}$ C. Lévi-Strauss, The Savage Mind, Chicago 1962. 


\section{Structure of events}

In times when the term storytelling is repeated in the advertising industry like a magical spell, we do not have to convince anybody that every brand needs a good story. The only matter of dispute is over what features such a story should possess. The solution put forward in this article assumes that an archetype of what is recognized as an attractive narrative is a myth. Not only are myths common, they are probably the oldest form of tale that ever existed. ${ }^{9}$ Regardless of historical or cultural distance, myths manifest an astonishing similarity to one another, which pertains in particular to the general types of events they present and the sequence of these events. On a certain level of generality, the myths of the Bororo people of the Amazon and the tales from Ancient Babylon, Greece, or Scandinavia turn out to be very similar to one another. This means that regardless of cultural differences, such a configuration of actions appears most interesting to people, and they want to hear about it in the stories they listen to, and if we agree that a good story is a story that we like to listen to, a myth can undeniably be considered a good story.

Investigators of the traditional narrative forms noticed the internal similarity of events described in myths relatively early. ${ }^{10}$ However, the most popular work about this issue has been the concept of the monomyth developed by Joseph Campbell. ${ }^{11}$ It has also practically been the only work to be occasionally applied in the field of marketing. The essence of Campbell's concept is an assumption that myths share a common structure of action sequence with rites of passage. To a certain degree they can be, therefore, treated as stories about transformation. The basic structure common to myths and rites of passage consists of three stages: the exclusion stage (separating an initiate from the rest of the society/the hero setting out on a journey); the transitional stage (the ritual change of the initiate's status/adventures of the mythical hero); and the inclusion stage (incorporating the initiate into the society according to his new status/return of the changed hero and the benefits that the society derives from his return). ${ }^{12}$

In the case of myth, in each of the above main stages we can further distinguish subsequent constant points. A standard protagonist of a myth is presented at the beginning in the context of his everyday life. Then he is called to leave that life, although he initially rejects this call. The decision to set out on a journey is finally made at the instigation of a wise helper, and the protagonist eventually goes beyond the boundaries of the world he knows. Travelling, he experiences many adventures that test him.

${ }^{9}$ M. Donald, Origins of the Modern Mind: Three Stages in the Evolution of Culture and Cognition, Cambridge 1991; E.G. d'Aquili, A.B. Newberg, The Mystical Mind: Probing the Biology of Religious Experience, Minneapolis 1999; A.B. Newberg, E.G. d'Aquili, V. Rause, Why God Won't Go Away: Brain, Science and the Biology of Belief, New York 2001.

${ }^{10}$ V. Propp, Morphology of the Folktale, Austin 1968; L. Raglan, The Hero: A Study in Tradition, Myth and Drama, Mineola 2013.

11 J. Campbell, The Hero with a Thousand Faces, New York 1949.

12 A. van Gennep, The Rites of Passage, London 2010; V. Turner, The Ritual Process: Structure and Anti-Structure, Chicago 1969. 
While he travels, he meets numerous helpers. Eventually, he reaches the place of the final test, which is usually an underground world or the stomach of a monster.

Other forms of trial include meeting a goddess, defeating a beast or other enemies, a confrontation with a lost father, or finding a treasure, a wife, or wisdom. At this point, the protagonist initially refuses to come back to the normal world - in the exact same way he had avoided starting the journey - and when he finally decides to go back, it turns out that he has to fight supernatural forces that chase him. Having defeated them, the hero comes back home, although he finds it difficult to adapt his new self to the old environment. The people he had left when setting out on the journey are now unsympathetic towards him. Eventually, however, the changed hero finds a way to fit into the reality, contributing - as an individual who has gained knowledge and artefacts from a different world - to the well-being of his society.

Thinking about the popularity of this particular arrangement of events, it is worth noticing that if we remove the fairytale coat from such stories, their essence in the form of such actions as setting out on a quest, escaping, and so on, might as well describe a typical day of a rat. ${ }^{13}$ A rat, like any other animal, has many needs which can be satisfied only outside of its safe nest. Therefore, willy-nilly, the animal has to leave the nest and deal with competitors and opponents in order to finally reach the place where it can satisfy its needs. Subsequently, avoiding many dangers, it has to go back to its safe den. It would actually be very difficult to find a more basic and, at the same time, important, story. Thus, it seems that the structure of the monomyth is so popular because it reflects a program of biological behaviors favorable for adaptation. In a simplified version we can therefore state that people consider to be a good story, a story that touches upon these basic, evolutionarily imprinted schemata of behaving in which, again, a myth is similar to a rite. ${ }^{14}$ In short: a myth is good because it is important from the point of view of adaptation. The magnetic power of the monomyth was discovered by Hollywood a long time ago. ${ }^{15}$ The structure of mythic events has been used to develop the screenplays of such blockbusters movies as Star Wars, The Matrix or The Lion King. Analogously, if a marketing branch wants to tell good stories, it should also avail itself of the structure of the monomyth.

\section{Bricolage}

Mythical thinking is characterized by an unwillingness to use abstract notions, although this does not mean that such notions are absent from it. Nevertheless, instead of manifesting themselves directly, they are represented by concrete objects, phenomena, or states. ${ }^{16}$

${ }_{13}$ W. Burkert, Structure and History in Greek Mythology and Ritual, Berkeley 1982; idem, Creation of the Sacred: Tracks of Biology in Early Religions, Cambridge 1996.

${ }^{14}$ T.E. Lawson, R.N. McCauley, Rethinking Religion: Connecting Cognition and Culture, Cambridge 1990; R.N. McCauley, T.E. Lawson, Bringing Ritual to Mind: Psychological Foundations of Cultural Forms, Cambridge 2002.

${ }^{15}$ Ch. Vogler, The Writer's Journey: Mythic Structure for Writers, Studio City 2007.

${ }^{16}$ C. Lévi-Strauss, The Savage Mind, op. cit. 
Therefore, myths do not directly address "death," "life," "freedom," or "happiness." Instead, they use animals, atmospheric phenomena, celestial bodies, or different types of foods which are somehow associated with particular abstract notions. To illustrate: in the myths of the Bororo the category of death manifests itself in the form of raw and rotten foods, and also animals that feed on this kind of foods (for example, a turtle that feeds on what is rotten, or a jaguar that feeds on what is raw). Life, on the other hand, is represented by fresh and cooked foods. ${ }^{17}$ This way, ordinary objects become mediums and operators of meanings from higher logical levels. Claude Lévi-Strauss called this manner of thinking "the logic of the concrete."

In a situation in which an abstract notion has to be expressed this way, bricolage becomes necessary. Having no terms dedicated to expressing abstract ideas at his disposal, the author of the myth has to act as a tinkerer. Having no access to specialized materials, he uses what he has at hand. An old wardrobe door was not initially intended to be a part of a kennel, although with a little bit of improvisation it can make a pretty fine roof for a kennel. On the semiotic plane, it operates in the following way: if the creator of a myth wants to express a particular abstract idea, he has to look around and select from the surrounding reality a concrete element that will become a carrier of this idea. If he wants to express the idea of death, he can do so by encoding it in the form of rotten food. However, it could just as well be expressed by the metaphor of a sunset, or the metonymic effect of death in the form of a skull. Thus, in the poetics of the myth, a rabbit is not simply a rabbit, but a symbol of fertility, whereas salt, poisonous to plants, is not simply a kitchen seasoning, but the symbol of a poor harvest, opposite to that of the rabbit. Each of these elements is not only an element in itself, but also an element of a specific code. ${ }^{18}$

The tendency of myth to operate on abstracts with the use of concrete objects should not be surprising in the light of its archaic genesis. The human mind is an embodied mind, as a result of which the abstract world of thoughts is arranged according to patterns of concrete kinesthetic and perceptive experiences. ${ }^{19}$ They emerge from what is concrete: from the ways of experiencing one's own body, simple operations on material elements, basic relations between real objects. The myth is a derivative of the initial phases of the process of transitioning from concrete to abstract, in which the abstract does not yet possess an independent raison d'être, remaining bound to its material background. Of importance, such a way of operating on the abstract is not only the oldest, but also the most natural for humans. Needless to say, this all should be taken into consideration in the process of building a story about a brand.

As a matter of fact, all models of marketing campaigns that assume that the features of the product are not important, but the ideas that stand behind it are, are a kind of bricolage. The product is in this type of campaign only a carrier of meaning and a means of accessing a set of attractive values. Judith Williamson emphasized, for instance, that the

${ }^{17}$ C. Lévi-Strauss, The Raw and the Cooked, trans. John and Doreen Weightman, New York 1969.

18 J. Bierhorst, The Red Swan: Myths and Tales of the American Indians, New York 1976; A.J. Greimas, Of Gods and Men: Studies in Lithuanian Mythology, Bloomington 1992.

${ }_{19}$ G. Lakoff, M. Johnson, Metaphors We Live By, Chicago 1980; iidem, Philosophy in the Flesh: The Embodied Mind and Its Challenge to Western Thought, New York 1999; M. Johnson, The Body in the Mind: The Bodily Basis of Meaning, Imagination, and Reason, Chicago 1990; G. Lakoff, Women, Fire, and Dangerous Things: What Categories Reveal About the Mind, Chicago 1987. 
function of certain consumer goods is identical with the function of totemic emblems as described by Lévi-Strauss. ${ }^{20}$ In both cases, these emblems confirm membership in a particular group of individuals who, admittedly, are not really related, but share common ideas. It is difficult, however, to tell apart the members of one clan from those of another. Despite possessing separate rites, feasts, or sacred objects, for the most part they look the same. In order to visualize the ideological difference, they therefore need distinctly different markers. Such markers can be animals, such as an eagle associated with the sky, or a bear associated with the earth, which, as a result, translates into the existence of the eagle clan and the bear clan. Contemporarily, the same role is played by particular products. We are people of either Pepsi or Coca-Cola, we ride either a Harley or a Vespa, we use either PCs or Macs, and behind each of these choices lie certain beliefs that we either consciously or unconsciously share. The bricolage technique enables success when the product offered under the given brand becomes a material representation of a set of such beliefs.

\section{Counter-intuitiveness}

It has been mentioned above that if we stripped the extraordinariness from a chain of mythical events, it would become a trivial sequence of basic, instinctive actions. One of the specific traits of myth is, however, the very presentation of images in an extraordinary manner. It so happens because the attractiveness of what is atypical is conducive to remembering. According to the terminology introduced by Dan Sperber, myths are public representations, sets of instructions that activate human cognitive processes in order to create a mental representation, which is a subjective model of a given phenomenon. ${ }^{21}$ The effectiveness of spreading representations understood this way is influenced by a number of factors. Some of them are of an environmentrelated nature (for example, the issue of the presence of either physical or social communication barriers), while others are psychological. Among factors from the latter category, particularly important, according to Sperber, is the degree to which the given representation can be committed to memory.

The possibility to remember a representation is, first of all, a sine qua non condition of participation of the given representation in the process of cultural transmission. Secondly, a higher effectiveness of remembering the given idea gives it an edge over ideas that are more difficult to remember, and this advantage, even if it is very small, gradually accumulates, yielding, with time, greater and greater results. One of the most significant questions that arises from the concept put forward by Sperber regards the conditions that facilitate remembering a given idea.

Representations in which appear atypical concepts possess in this respect a certain advantage, because they stand out against the background of other concepts, thanks

20 J. Williamson, op. cit.; C. Lévi-Strauss, Totemism, trans. R. Needham, Boston 1963.

${ }^{21}$ D. Sperber, The Modularity of Thought and the Epidemiology of Representations, [in:] Mapping the Mind: Domain Specificity in Cognition and Culture, L.A. Hirschfeld, S.A. Gelman (eds.), Cambridge 2002, pp. 39-67. 
to which they are better remembered. This does not apply, however, to all atypical concepts, but only to their particular kind, defined as counterintuitive concepts, meaning concepts that to a certain degree are contradictory to intuitive knowledge human beings possess about psychology, biology, and physics. ${ }^{22}$ This knowledge allows a person to spontaneously classify elements of the surrounding world into selfconscious humans, conscious animals, living but unconscious plants, and physical objects. The individual also possesses a certain set of beliefs about each of these categories. The person knows, for instance, that human beings and animals are directed by non-physical motivations, while physical objects cannot be in two places at the same time. On the basis of such assumptions people change their behavior so that it is more appropriate. They do not, for example, attempt to go through a wall, tease a lion, or take things that belong to other people when they are not looking. Most such basic categories that refer to beings have been called ontological categories by Pascal Boyer. ${ }^{23}$

As opposed to other atypical concepts, counterintuitive concepts stand in contradiction to what we know about ontological categories. From elements classified in the category of PERSON we intuitively expect, for instance, that they will possess a physical body, specific mental states, emotions, and so on. To take away even one of these attributes is to render such a concept counterintuitive. An example of such a situation would be a ghost, a person without a physical body, or its opposite - a zombie, a physical body of a human being deprived of mental states typical for human beings. A different manner of building counterintuitive concepts is transferring attributes between categories. Thus, another counterintuitive concept would a talking dog (the category ANIMAL plus an attribute taken from the category PERSON), or a statue that hears human requests (the category ARTEFACT plus an attribute taken from the category PERSON). ${ }^{24}$ In turn, a person who weighs five hundred kilos or a madman could not be a counterintuitive concept. Both of these examples are in a sense indeed unusual, but their unusualness consists in an atypical manner of realizing attributes otherwise typical for the category PERSON (the physical body in the former case and mental states in the latter). Concepts of this kind do not show the same predisposition to be as easily remembered as counterintuitive concepts. The effect of a high level of remembering also disappears when concepts are counterintuitive to a degree higher than minimal. They then become then too complicated for the human cognitive apparatus to easily operate on them. The traditional narrative material, including myths, shows all traits of representations built according to the

22 J.L. Barrett, M.A. Nyhof, Spreading Non-natural Concepts: The Role of Intuitive Conceptual Structures in Memory and Transmission of Cultural Materials, "Journal of Cognition and Culture" 2001, vol. 1, no. 1, pp. 69-100; P. Boyer, Ch. Ramble, Cognitive Templates for Religious Concepts: Cross-cultural Evidence for Recall of Counter-intuitive Representations, "Cognitive Science" 2001, vol. 25, no. 4, pp. 535-564; A. Norenzayan, S. Atran, Cognitive and Emotional Processes in the Cultural Transmission of Natural and Nonnatural Beliefs, [in:] The Psychological Foundations of Culture, M. Schaller, C.S. Crandall (eds.), Mahwah 2004, pp. 149-169; A. Norenzayan, S. Atran, J. Faulkner, M. Schaller, Memory and Mystery: The Cultural Selection of Minimally Counterintuitive Narratives, "Cognitive Science" 2006, vol. 30, no. 3, pp. 531-553.

${ }^{23}$ P. Boyer, Religion Explained: The Evolutionary Origins of Religious Thought, New York 2001.

${ }^{24}$ P. Boyer, Ch. Ramble, op. cit. 
rule of minimal counter-intuitiveness. ${ }^{25}$ Therefore, if one wants a story about a brand to combine the attractiveness of communication with a high degree of memorability, they also should observe the rule of minimal counter-intuitiveness.

\section{Types of mythologization processes}

The knowledge of the specific attributes of myths is, naturally, absolutely necessary in the process of creating a myth-like marketing message. It is not, however, sufficient, for the knowledge of myth is not equivalent to the knowledge of the process of mythologization. Besides, mythologization still remains a topic that, as opposed to the issue of the myth itself, has not been sufficiently explored, as well as outside the world of advertising. Meanwhile, even if we understand mythologization in a very general manner, as a process of making something a myth, then such a process in marketing can be understood in at least the following three ways:

\section{Modelling,}

2. Export,

3. Import.

By the first process I mean a situation in which we avail ourselves of the knowledge of myth and develop a marketing campaign so that its components possess attributes analogous to myth. The sources to which creators of such campaigns refer are theoretical works about myth, and not actual mythological systems. The second process, export, pertains to a situation in which marketing takes an existing mythological system and tries to shape a campaign in such a way as to make a given brand an element of this system. The third process, import, refers in turn to the opposite situation, one in which elements of existing mythological systems appear among components of a marketing campaign. These elements are, however, taken out of their original context and along with the advertised brand they create a new whole against the background of the preexisting mythological systems.

In practice, the methods of brand mythologization described above are rather ideal types and in reality the boundaries among them are fluid. For instance, it is often difficult to unequivocally state whether a counterintuitive concept created for a given marketing campaign is built solely on the basis of theoretical rules of creating such concepts or is patterned on counterintuitive concepts that already function in a given culture. However, if we preserve a relative distinction between the particular types of mythologization and connect them with the three characteristics of myth discussed above, we will obtain a matrix composed of nine techniques, which can be applied to a marketing campaign that aims at mythologizing a given brand (Table 1).

${ }^{25}$ A. Norenzayan, S. Atran, J. Faulkner, M. Schaller, op. cit.; J.L. Barrett, E.R. Burdett, T.J. Porter, Counterintuitiveness in Folktales: Finding the Cognitive Optimum, "Journal of Cognition and Culture" 2009, vol. 9, no. 3, pp. 271-287. 


\begin{tabular}{|c|c|c|c|}
\hline $\begin{array}{l}\text { Characteristic of the } \\
\text { myth / type of my- } \\
\text { thologization }\end{array}$ & Modelling & Export & Import \\
\hline Structure of events & $\begin{array}{l}\text { Building a story } \\
\text { about the brand } \\
\text { on the basis of } \\
\text { the theoretical } \\
\text { scheme of the } \\
\text { monomyth }\end{array}$ & $\begin{array}{l}\text { Making the } \\
\text { brand an element } \\
\text { of an existing } \\
\text { monomyth-like } \\
\text { story }\end{array}$ & $\begin{array}{l}\text { Using elements } \\
\text { of a concrete } \\
\text { monomyth in the } \\
\text { structure of a story } \\
\text { about the brand }\end{array}$ \\
\hline Bricolage & $\begin{array}{l}\text { Building } \\
\text { associations between } \\
\text { the product and } \\
\text { abstract meanings }\end{array}$ & $\begin{array}{l}\text { Making the } \\
\text { product a carrier } \\
\text { of meanings } \\
\text { that function } \\
\text { in a concrete } \\
\text { mythological } \\
\text { system }\end{array}$ & $\begin{array}{l}\text { Using objects that } \\
\text { are standard carriers } \\
\text { of meaning within } \\
\text { the framework of } \\
\text { a given mythologi- } \\
\text { cal system }\end{array}$ \\
\hline Counterintuitiveness & $\begin{array}{l}\text { Creating new } \\
\text { counterintuitive } \\
\text { concepts }\end{array}$ & $\begin{array}{l}\text { Joining the pro- } \\
\text { duct with existing } \\
\text { counterintuitive } \\
\text { concepts that occur } \\
\text { in their "natural" } \\
\text { context }\end{array}$ & $\begin{array}{l}\text { Using in a story } \\
\text { about the brand } \\
\text { counterintuitive } \\
\text { concepts that } \\
\text { originate from } \\
\text { an existing } \\
\text { mythological system, } \\
\text { however, taken out } \\
\text { of their "natural" } \\
\text { context }\end{array}$ \\
\hline
\end{tabular}

Table 1. Matrix of techniques of brand mythologization.

These nine techniques can be applied irrespectively of one another. For instance, we can be content with using only the scheme of the monomyth and use neither bricolage nor counterintuitive concepts. We can, however, use all three types of techniques connected with the characteristics of the myth. In this latter case, we can, in turn, apply techniques connected with one of the types of mythologization distinguished here or, along with changing the characteristic of the myth, shift the emphasis from one type of mythologization to the other. Thus, we can combine, for instance, import of the monomyth structure with modelling counter-intuitiveness, and so on.

I would not like to prejudge here whether applying only one of the techniques presented here enables us to talk about mythologization of a brand or not, for I think that mythologization is a gradable feature. It is obvious, nevertheless, that the more techniques associated with characteristics of myth, the more intensive the process of brand mythologization. For an assessment of the degree of mythologization, however, it does not matter which type of mythologization has been used to assign particular characteristics of the myth to the brand. In Table 2, I present examples of marketing actions in which, either intentionally or unintentionally, one of the techniques described here has been applied. 


\begin{tabular}{|c|c|c|c|}
\hline $\begin{array}{l}\text { Characteristic of the } \\
\text { myth / type of my- } \\
\text { thologization }\end{array}$ & Modelling & Export & Import \\
\hline Structure of events & $\begin{array}{l}\text { The Coca-Cola ad } \\
\text { Road to Happiness } \\
\text { Factory [a journey to } \\
\text { the brand's original } \\
\text { world, created accor- } \\
\text { ding to the scheme } \\
\text { of the monomyth] }\end{array}$ & $\begin{array}{l}\text { Placing the Aston } \\
\text { Martin cars in the } \\
\text { movies about James } \\
\text { Bond [incorporating } \\
\text { the product into } \\
\text { an existing story } \\
\text { of the monomyth } \\
\text { character] }\end{array}$ & $\begin{array}{l}\text { The Red Riding } \\
\text { Hood ad of Chanel } \\
\text { No. } 5 \text { [an original } \\
\text { variation on an } \\
\text { existing mono- } \\
\text { myth-like story] }\end{array}$ \\
\hline Bricolage & $\begin{array}{l}\text { Building associa- } \\
\text { tions between the } \\
\text { Mountain Dew } \\
\text { brand and values of } \\
\text { the demotic culture } \\
\text { [creating an original } \\
\text { connection between } \\
\text { a product and a me- } \\
\text { aning that does not } \\
\text { constitute an element } \\
\text { of any existing } \\
\text { mythological sy- } \\
\text { stem] }\end{array}$ & $\begin{array}{l}\text { The ad of Axe deo- } \\
\text { dorant. In the spot } \\
\text { Even Angels Will } \\
\text { Fall the characteri- } \\
\text { stic of this product } \\
\text { motif of sexual lust } \\
\text { has been additional- } \\
\text { ly associated with } \\
\text { the biblical motif } \\
\text { of a fall [creating } \\
\text { a new medium for } \\
\text { a standard element } \\
\text { of the Christian } \\
\text { mythology] }\end{array}$ & $\begin{array}{l}\text { The Smirnoff } \\
\text { Apple Bite cam- } \\
\text { paign that uses the } \\
\text { biblical meaning } \\
\text { of an apple (apple } \\
\text { = temptation) } \\
\text { [using a standard } \\
\text { for the Christian } \\
\text { mythology material } \\
\text { medium of the } \\
\text { notion of } \\
\text { "temptation"] }\end{array}$ \\
\hline Counterintuitiveness & $\begin{array}{l}\text { A lamp that has } \\
\text { feelings from the } \\
\text { IKEA's spot Lamp } \\
\text { [creating a new } \\
\text { counterintuitive } \\
\text { concept] }\end{array}$ & $\begin{array}{l}\text { Red Bull ads, in } \\
\text { which a can of be- } \\
\text { verage is added to } \\
\text { well-known mytho- } \\
\text { logical and legenda- } \\
\text { ry scenes (with Jesus, } \\
\text { angels, a genie, or } \\
\text { a prince turned into } \\
\text { a frog) [using exist- } \\
\text { ing counterintuitive } \\
\text { concepts along with } \\
\text { their standard con- } \\
\text { text] }\end{array}$ & $\begin{array}{l}\text { Using the figure } \\
\text { of Santa Claus in } \\
\text { Coca-Cola ads } \\
\text { [using existing co- } \\
\text { unterintuitive con- } \\
\text { cepts outside the } \\
\text { standard context of } \\
\text { their appearance] }\end{array}$ \\
\hline
\end{tabular}

Table 2. Examples of marketing actions in which particular brand mythologization techniques have been applied.

To supplement the examples in Table 2 with additional commentary, it can be stated that modelling the structure of events on the basis of the monomyth scheme will practically always have to be done when a given advertisement is based upon the pattern of transitioning to a different world. This "different world" can be literally different (an underworld, a paradise, different dimensions, remote planets), or metaphorically 
different - it can mean detachment from everyday life (an adventure, an excursion, extreme experiences). Every narration built on such a pattern will bear the characteristics of an initiation story. In turn, exporting a brand to an existing monomyth will have to be done each time product placement takes place within the framework of an existing world that possesses mythical characteristics. In this case as well it can be a mythology sensu stricto (Greek mythology, Christian, Nordic, etc.) or a fictional "mythicized" reality (the universe of Star Wars or The Matrix movies).

An analogous situation takes place in the importing of mythical elements. Their source can be either classic myths or a "mythicized" reality. As a result, brand mythologization can be realized by referring to the biblical motif of an apple as well as by referring to lightsabers or the $\mathrm{X}$-wing. In each of these cases the authors avail themselves of archaic techniques of motivation that remain independent of rational knowledge about a given fragment of reality. These operations are, however, natural for the architecture of human minds and, in consequence, they are an effective means of influencing people. Therefore, if marketing needs effective tools of shaping attitudes that do not refer to consumers' knowledge, then myth should be considered to be their natural source, a source that can be exploited in one of the nine ways described in the present article.

\section{References}

Barrett J.L., Nyhof M.A., Spreading Non-natural Concepts: The Role of Intuitive Conceptual Structures in Memory and Transmission of Cultural Materials, "Journal of Cognition and Culture" 2001, vol. 1, no. 1, pp. 69-100.

Barrett J.L., Burdett E.R., and Porter T.J., Counterintuitiveness in Folktales: Finding the Cognitive Optimum, "Journal of Cognition and Culture" 2009, vol. 9, no. 3, pp. 271-287.

Belk R.W., Tumbat G., The Cult of Macintosh, "Consumption, Markets and Culture" 2005, vol. 8, no. 3, pp. 205-217.

Bierhorst J., The Red Swan: Myths and Tales of the American Indians, New York 1976.

Boyer P., Ramble Ch., Cognitive Templates for Religious Concepts: Cross-cultural Evidence for Recall of Counter-intuitive Representations, "Cognitive Science” 2001, vol. 25, no. 4, pp. 535-564.

Boyer P., Religion Explained: The Evolutionary Origins of Religious Thought, New York 2001.

Brown S., McDonagh P., Shultz C.J., Titanic: Consuming the Myths and Meanings of an Ambiguous Brand, "Journal of Consumer Research" 2013, vol. 40, no. 4, pp. 595-614.

Burkert W., Creation of the Sacred: Tracks of Biology in Early Religions, Cambridge 1996.

Burkert W., Structure and History in Greek Mythology and Ritual, Berkeley 1982.

Campbell J., The Hero with a Thousand Faces, New York 1949.

d'Aquili E.G., Newberg A.B., The Mystical Mind: Probing the Biology of Religious Experience, Minneapolis 1999.

Donald M., Origins of the Modern Mind: Three Stages in the Evolution of Culture and Cognition, Cambridge 1991.

Doty W.G., Mythography: The Study of Myths and Rituals, Tuscaloosa 2000.

Gennep A. van, The Rites of Passage, London 2010.

Greimas A.J., Of Gods and Men: Studies in Lithuanian Mythology, Bloomington 1992.

Heath R., The Hidden Power of Advertising: How Low Involvement Processing Influences the Way We Choose Brands, Henley-on-Thames 2001. 
Holt D.B., Cameron D., Cultural Strategy: Using Innovative Ideologies to Build Breakthrough Brands, Oxford 2012.

Holt D.B., How Brands Become Icons: The Principles of Cultural Branding, Boston 2004.

Holt D.B., What Becomes an Icon Most?, "Harvard Business Review" 2003, vol. 81, no. 3, pp. 43-49.

Honko L., The Problem of Defining Myth, [in:] The Myth of the State, H. Biezais (ed.), Stockholm 1972, pp. 7-19.

Johar G.V., Holbrook M.B., Stern B.B., The Role of Myth in Creative Advertising Design: Theory, Process and Outcome, "Journal of Advertising" 2001, vol. 30, no. 2, pp. 1-25.

Johnson M., The Body in the Mind: The Bodily Basis of Meaning, Imagination, and Reason, Chicago 1990.

Kilinc U., The Use of Myths as an Advertisement Strategy at the Age of Social Media, [in:] Handbook of Research on Effective Advertising Strategies in the Social Media Age, Ö.T. Nurdan, Y. Recep (eds.), Hershey 2015, pp. 406-415.

Lakoff G., Johnson M., Metaphors We Live By, Chicago 1980.

Lakoff G., Johnson M., Philosophy in the Flesh: The Embodied Mind and Its Challenge to Western Thought, New York 1999.

Lakoff G., Women, Fire, and Dangerous Things: What Categories Reveal About the Mind, Chicago 1987.

Lawson T.E., McCauley R.N., Rethinking Religion: Connecting Cognition and Culture, Cambridge 1990.

Lévi-Strauss C., The Savage Mind, Chicago 1962.

Lévi-Strauss C., Totemism, trans. R. Needham, Boston 1963.

Lévi-Strauss, C., The Raw and the Cooked, trans. John and Doreen Weightman, New York 1969.

Levy S.J., Interpreting Consumer Mythology: A Structural Approach to Consumer Behavior, "Journal of Marketing" 1981, vol. 45, no. 3, pp. 49-61.

Mark M., Pearson C., The Hero and the Outlaw: Building Extraordinary Brands Through the Power of Archetypes, New York 2001.

McCauley R.N., Lawson T.E., Bringing Ritual to Mind: Psychological Foundations of Cultural Forms, Cambridge 2002.

Newberg A.B., d'Aquili E.G., Rause V., Why God Won't Go Away: Brain, Science and the Biology of Belief, New York 2001.

Norenzayan A., Atran S., Cognitive and Emotional Processes in the Cultural Transmission of Natural and Nonnatural Beliefs, [in:] The Psychological Foundations of Culture, M. Schaller, C.S. Crandall (eds.), Mahwah 2004, pp. 149-169.

Norenzayan A., Atran S., Faulkner J., Schaller M., Memory and Mystery: The Cultural Selection of Minimally Counterintuitive Narratives, "Cognitive Science” 2006, vol. 30, no. 3, pp. 531-553.

Propp V., Morphology of the Folktale, Austin 1968.

Raglan L., The Hero: A Study in Tradition, Myth and Drama, Mineola 2013.

Randazzo S., Mythmaking on Madison Avenue: How Advertisers Apply the Power of Myth and Symbolism to Create Leadership Brands, Chicago 1993.

Randazzo S., Subaru: The Emotional Myths Behind the Brand's Growth, "Journal of Advertising Research" 2006, vol. 46, no. 1, pp. 11-17.

Sperber D., The Modularity of Thought and the Epidemiology of Representations, [in:] Mapping the Mind: Domain Specificity in Cognition and Culture, L.A. Hirschfeld, S.A. Gelman (eds.), Cambridge 2002, pp. 39-67.

Stern B.B., Consumer Myths: Frye's Taxonomy and the Structural Analysis of Consumption Text, "Journal of Consumer Research" 1995, vol. 22, no. 2, pp. 165-185.

Strenski I., Four Theories of Myth in Twentieth-Century History: Cassirer, Eliade, Lévi-Strauss and Malinowski, London 1995. 
Thompson C.J., Marketplace Mythology and Discourses of Power, "Journal of Consumer Research" 2004, vol. 31, no. 1, pp. 62-80.

Turner V., The Ritual Process: Structure and Anti-Structure, Chicago 1969.

Vincent L., Legendary Brands: Unleashing the Power of Storytelling to Create a Winning Marketing Strategy, Chicago 2002.

Vogler Ch., The Writer's Journey: Mythic Structure for Writers, Studio City 2007.

Williamson J., Decoding Advertisements: Ideology and Meaning in Advertising, London 1978. 